\title{
In Search of Identity and Legitimation
}

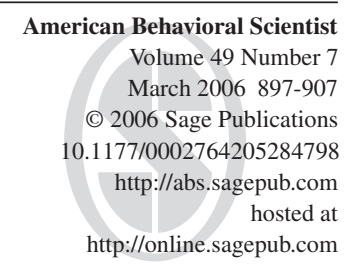

\section{Bridging Organizational Culture and Neoinstitutionalism}

\author{
Jesper Strandgaard Pedersen \\ Copenhagen Business School, Denmark \\ Frank Dobbin \\ Harvard University
}

\begin{abstract}
In the late 1970s, neoinstitutional and organizational culture theorists challenged prevailing rationalist organizational paradigms by introducing social constructionism to the field of organizations. Despite their common foundation, these approaches built on seemingly contradictory empirical observations. Institutionalists observed that organizations actively copy one another's practices, resulting in substantial isomorphism, whereas culture theorists observed that organizations institutionalize distinctive cultures comprising practices that set them apart from others. These seemingly contradictory findings reflect processes of organizational identity formation and interorganizational construction of legitimacy as they have evolved since the rise of the corporate form in the 19th century. Formation of identity through uniqueness and construction of legitimacy through uniformity are two sides of the same coin. Research on management schools suggests organizations pursue individuation through uniqueness and legitimacy through commonality simultaneously and that organizations bridge the two processes in four ways, which the authors dub imitation, hybridization, transmutation, and immunization.
\end{abstract}

Keywords: identity; legitimation; organizational culture; neoinstitutionalism; isomorphism

$\mathbf{I}_{\mathrm{a}}^{\mathrm{t}}$

seems paradoxical that in the late 1970s, two social constructionist reactions against hyperrationalist theories of organization emerged that were based on contrary conceptions of the role of culture and meaning in organizations. According to neoinstitutional theorists, meaning is socially constructed among large numbers of organizations through the creation of shared practices and the collective attribution of rationality or justice to those practices (DiMaggio \& Powell, 1983, 1991; Meyer \&

Authors' Note: We thank Raghu Garud, Mary Jo Hatch, Kristian Kreiner, Joanne Martin, John Meyer, Steen Scheuer, and Marc Schneiberg for their suggestions. 
Rowan, 1977; Scott, 1995). According to organizational culture theorists, meaning is socially constructed within organizations through the creation of unique practices and the collective attribution of significance and identity to those practices (Frost, Moore, Louis, Lundberg, \& Martin, 1985; Martin, 1992, 2002; Pettigrew, 1979; Smircich, 1983).

The paradox is seldom discussed in the literature, in large part because these two lines of research evolved independently. In this article, we compare and discuss these two research traditions in an effort to understand the empirical phenomena they depict in general terms. Then we use recent studies of management schools to derive four models of how organizations bridge the two processes to internalize practices from the organizational field.

Evidence to support our argument comes from the findings of neoinstitutional and cultural researchers themselves. By the late 1990s, substantial theoretical and empirical literatures could be found in each camp. For overviews of the culture camp see, for example, the special issue of Jelinek, Smircich, and Hirsch (1983), Frost et al. (1985), Alvesson and Berg (1988), Van Maanen (1988), Gagliardi (1990), Schein (1992), and Martin (1992, 2002); for overviews of the neoinstitutional camp see, for example, DiMaggio and Powell (1991), Scott and Meyer (1994), Dobbin (1994), Scott (1995), and Dacin, Goodstein, and Scott (2002). Both theories were founded on empirical observations, and by now we have considerable evidence that the processes described by these schools are regularities of the organizational world. On one hand, we know that actors in organizations copy practices, and justificatory rhetorics, that they observe in the environment in the hope of symbolizing, and effecting, the prime legitimate goals of modernity: rationality and justice. Culture and practice in organizations are sometimes intentionally and conspicuously imported from the environment. On the other hand, we know that actors in organizations create unique practices, and justificatory rhetorics, to distinguish their organizations and to symbolize, and effect, the goals of rationality and justice. Culture and practice are intentionally created anew and celebrated by actors within organizations.

The antinomy between the central findings of neoinstitutional and organizational culture theories, we argue, reflects a wider social process in which organizations create legitimacy by adopting recognizable forms and create identity by touting their uniqueness. In painting and poetry, established genres and their artistic rules set parameters within which creativity occurs. In management, industries and their institutionalized forms set parameters within which organizational cultures occur. We compare the findings of neoinstitutionalists and organizational culture theorists to adjudicate between competing explanations of these processes of isomorphism and polymorphism among organizations. We argue that these theories depict two sides of the process of the social construction of the corporation as actor. To further specify the nature of these processes, we illustrate with research on management schools showing four different ways in which organizations respond to institutionalized practices. 
Table 1 Neoinstitutional Theory and Organizational Culture Theory

\begin{tabular}{lll}
\hline & \multicolumn{1}{c}{ Neonstitutional Theory } & Organizational Culture Theory \\
\hline Paradigm & Social construction & Social construction \\
Research object & Collective meaning structures & Collective meaning structures \\
Level of analysis & Groups of organizations & Groups of individuals \\
& Interorganizational relations & Intraorganizational relations \\
Method & Quantitative & Qualitative \\
& Event history & Case studies \\
System assumptions & Open & Closed \\
& Interaction & Isolation \\
Explanandum & Change & Continuity \\
& Isomorphism & Polymorphism \\
Explanans & Search for legitimation & Search for identity \\
& Meaning among organizations & Meaning within organizations \\
\hline
\end{tabular}

\section{Culture as Uniformity—Culture as Uniqueness}

The two new cultural approaches to organizations that emerged in the late 1970s reacted against the hyperrationalist organizational theories that prevailed at that time. The received, functionalist, wisdom was that isomorphism among economic organizations occurred because the corporate form was the optimal form for organizing economic activity. This idea was epitomized in Ronald Coase's (1937) theory and in James Coleman's (1990) empirical description. The functionalist wisdom was that uniqueness among organizations occurred because division of labor among units was optimal.

Both cultural schools reacted against functionalist determinacy. But whereas neoinstitutional scholars reacted against functionalism's neglect of the social construction of rationalized meaning among modern organizations, organizational culture scholars reacted against functionalism's neglect of the construction of informal practice and leadership within organizations. Being reactions against different deficiencies of prevailing organizational theories, neoinstitutional theory and organizational culture theory moved in quite different empirical and theoretical directions. The two camps, however, share much. Both focus on the creation of collective meaning structures through social processes (see Table 1). Both are concerned with the symbolic and cognitive aspects of organizational life; both trace their intellectual roots to the social constructionism of Peter Berger and Thomas Luckmann (1966). Both view existing rationalist explanations of organizations as leaving significant residual variance to explain - unable to capture the roles of explanation, interpretation, emotion, values, and belief in organizations. Both view conventional organizational theories as fundamentally asociological, in that they turn the precepts of the rationalized worldview back on the modern organization as an analytic frame and thereby attribute 
socially constructed notions of rationality to universal, extrasocietal, laws (Strandgaard Pedersen \& Dobbin, 1997).

\section{Contradictory Findings From a Common Epistemology}

Despite their common point of departure in social constructionist thought, these two bodies of research have chronicled processes that seem to be at odds. This is a matter of focus and method, we argue. Being based in the sociological tradition, institutionalists look for similarities among organizations; being based in the symbolic anthropological and social psychological traditions, organizational culture researchers look for similarities across individuals within organizations. Being built on the sociological tradition, institutional theorists treat the organization as the appropriate level of analysis; being built on the interpretive sociological tradition and being influenced by both anthropology and social psychology, culturalists treat the small group as the appropriate level of analysis. Their sociological method leads institutionalists to explain particular practices by tracking their spread across organizations with quantitative techniques; their anthropological method leads organizational culture researchers to examine holistic organizational cultures with ethnographic methods and qualitative techniques. The sociological method leads institutionalists to explain changes that produce isomorphism within populations of organizations; the interpretive method leads organizational culturalists to explain continuity in informal practice and sense making that produce polymorphism among organizations.

The institutional approach stems from the growing sociological view of organizations as open systems, found in institutionalists' emphasis on organizationenvironment relations, stress on interaction and interchange between organizations, and depiction of imitation and diffusion as central processes in organizational legitimation. By contrast, the organizational culture approach is based on a closed systems perspective marked by the explanation of organizational life with reference to intraorganizational factors-found in the emphasis on organizational isolation and the downplaying of interaction among organizations-and characterized by a focus on internal learning and socialization processes in the organizational search for identity. Thus, institutionalists look for interorganizational convergence, isomorphism, and meaning construction through interorganizational paradigm construction; organizational culture researchers look for organizational divergence, polymorphism, and identity construction through collective sense making.

\section{Two Sides of the Same Coin}

Although organizational cultures depend on their sense of distinctiveness for the construction of organizational identity (Albert, Ashforth, \& Dutton, 2000; Albert \& Whetten, 1985), empirical studies show that cultures are often composed of common components (Glynn \& Abzug, 2002). Martin, Feldman, Hatch, and Sitkin (1983) first made the point in their study "The Uniqueness Paradox of Organizational Studies." 
Organizations claim uniqueness, but at any point in time, organizations claim similar sorts of uniqueness. This was, after all, the bottom line of Peters and Waterman's (1982) best seller on corporate cultures, In Search of Excellence - all great organizations share key cultural characteristics. Organizational cultures are commonly defined against an uncharismatic vision of how mundane organizations operate that is shared at the interorganizational level and, thus, organizations frame their distinctive cultures against a common antihero. Moreover, in practice, managers draw on successful examples to construct their local cultures, and the process often resembles the process of diffusion that institutionalists describe. Thus, when managers talk of empowerment or whatever may be in vogue, they often link fashionable precepts of informal organization with their company histories, rehearsing ideas they get from the environment as components of their organization's culture. Building blocks of conscious organizational culture often come from the environment, with the result that distinctive organizational cultures can be surprisingly similar to one another at any point in time. When managers began to believe in the efficacy of "strong" or "excellent" cultures, they began to deliberately construct local cultures from the building blocks they find in the environment. From the perspective of institutionalists, the very need for a unique organizational culture has diffused as part of the prescription for managerial action.

Institutionalists argue that the process of isomorphism continues today, as organizations of all sorts that were previously thought to be structured by their particular functions in society or by national cultural traditions take identical forms (Meyer, 1994). Increasingly, management forms and trends once thought to apply exclusively to private corporations are embraced by religious orders, nonprofit universities, and athletic clubs (e.g., Christensen \& Molin, 1995). Particular organizational formsoriented to sectarianism, intellectual life, or gamesmanship—are disappearing. Yet although institutionalists recognize organizational fads-total quality management, empowerment, open-door management—organizational culture researchers contend that convergence in practices can belie substantial differences in the meaning attached to those practices in different organizations. Elements of meaning will be local and contextual, students of organizational culture contend. The findings of culture researchers suggest that by focusing on structural isomorphism, institutionalists exaggerate actual commonalities in organizational life. Here their arguments come very close to those of early institutionalists who argued that formal practices may be decoupled from actual behavior (Meyer \& Rowan, 1977; Selznick, 1949, 1957; Zucker, 1977). We suggest that the empirical processes identified in these studies are part of an important duality in modern social life, the duality of institutionalized meaning and identity as it has come to constitute the organization.

\section{A Model of Ambimorphism?}

In various ways, studies address the idea of the formation of identity through uniqueness and the construction of legitimation through uniformity as dual processes constituting the organization. In discussing individual identity, Gioia (1998) argued 
that "maintaining the balance between similarity and difference is one of the most challenging and interesting issues for the understanding" (p. 20) of identity. With the notion of "optimal distinctiveness," Brewer (1991) described social identity as a reconciliation of conflicting needs for assimilation and differentiation. In a similar vein, Røvik (1998) noted that

comparison is a central process in relation to developing an identity. Identity is created by comparing oneself with—and by being compared with—other entities. Identity is therefore a relational phenomenon. It is always defined in relation to someone or something. (p. 13)

These contributions are primarily theoretical and conceptual. Empirical illustrations are provided by Porac, Thomas, Wilson, and Kanfer (1995) in their study of the Scottish knitwear industry and by Lant and Baum (1995) in their study of managers in the Manhattan hotel industry. Porac et al. identified a socially constructed industry model, which is composed of general types where members define themselves and their positions as unique in relation to a reference group of rivals. Lant and Baum identified different strategic groups in the Manhattan hotel industry, showing how managerial cognition, shared beliefs, and isomorphic practices contribute to the emergence of groups with distinct identities.

Harrison White's theory of market formation depicts the duality well. In their depiction of the frozen-pizza industry, Leifer and White (1987) described institutionalized industry roles that are arrayed on standard dimensions, such as price and production quantity. The available roles are scripted not only at the industry level but also at the economy-wide level—mass marketer (moderate price, high quantity), high end (high price, low quantity), and discounter (low price, high quantity). Market entrants choose a unique identity in relation to existing market participants, and they typically look for a role that is not oversubscribed so as to escape competition. The idea is that the dimensions on which you can distinguish yourself are highly institutionalized (price, quantity, advertising strategy), and so are the specific market roles; but the result is that organizations claim distinct, but recognizable, market identities. Figure 1 depicts how the elements of this dual process come together.

One of the challenges for this model lies in specifying more concretely the types of social transformation processes through which the dual processes of identity formation and isomorphism are bridged. Recent studies of management schools in Europe, conducted by the first author and his collaborators, provide material that illustrates four bridging approaches. In a comparison of master of business administration (MBA) programs in Denmark, Italy, Spain, and Sweden, Mazza, Sahlin-Andersson, and Strandgaard Pedersen (2005) found that the circulation of a vague model, such as the MBA program, allows for both variance in the local application and conformity to a common core. Business schools in Europe introduced the MBA program only in the past few decades. Although the MBA program has diffused widely, becoming perhaps the dominant model for management education, each of the European programs is a distinctly local translation of the global model. 
Figure 1

The Social Construction of the Organization

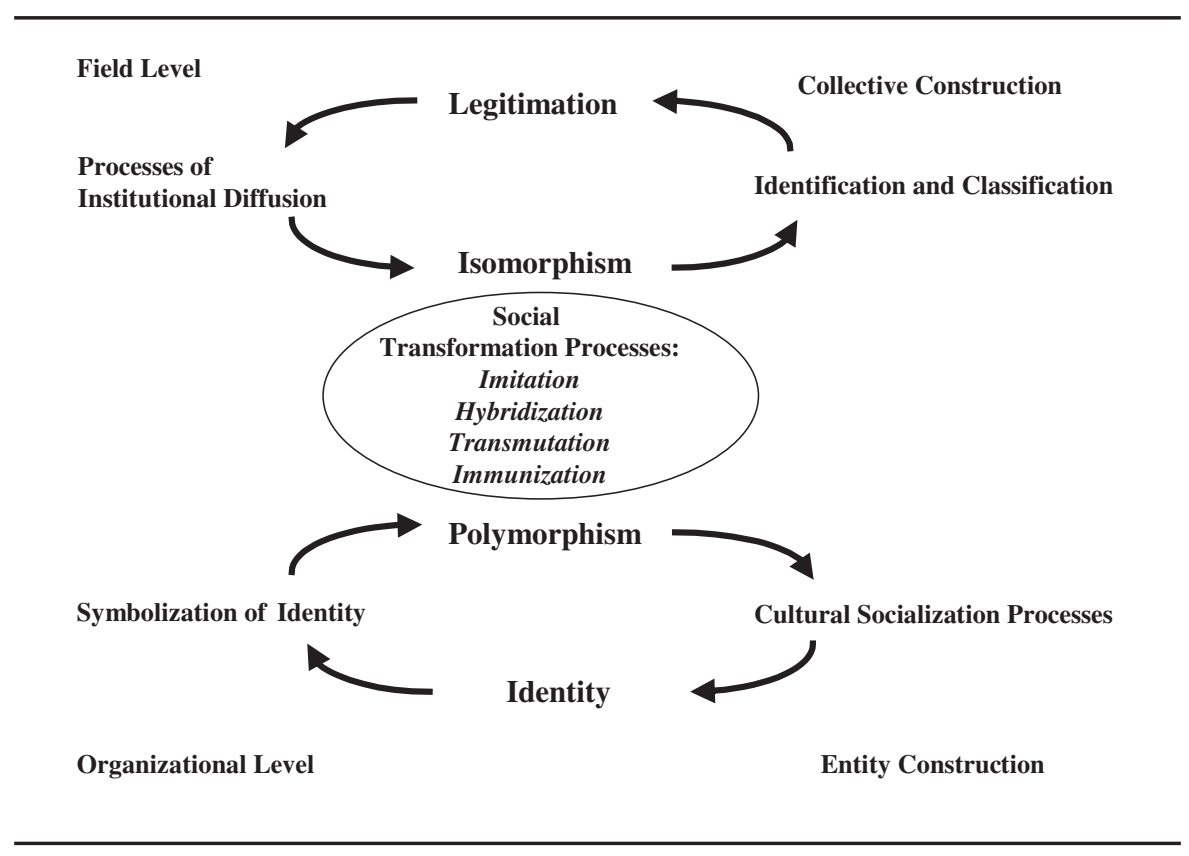

In another study of management education and MBA programs, Boutaiba and Strandgaard Pedersen (2003) explained how those who introduced the MBA program at the Copenhagen Business School created a distinct identity within the field. They identified a generic model based on a comparison of 10 European MBA programs and argued that the parameters of this general model were constructed at the field level by early adopters, accreditation associations, and those who developed ranking systems. These groups defined central elements and "building blocks" (e.g., with regard to "admission procedure," "student profile," "tuition and fees"). Then the architects of the Copenhagen Business School MBA program used the key building blocks to gain legitimacy and developed a distinct program to create an identity.

Findings from these studies of MBA programs suggest that four different kinds of mechanisms mediate the relationship between global and local models of organizing: imitation, hybridization, transmutation, and immunization.

Imitation occurs when new practices are copied wholesale. The case of IESE Business School at the University of Navarra, Spain, is illustrative. IESE sought to establish legitimacy by replicating the Harvard Business School MBA program as perfectly as possible (Mazza et al., 2005).

Hybridization takes place when local organizational elements are combined with field-level elements. This process resembles "bricolage" (Campbell, 1997) and is best illustrated by the Copenhagen Business School MBA program, which combined local elements - for example, the 13-point grading scale and the long-standing examination 
format - with global elements-for example, an alumni organization and admission based on the GMAT, the Test of English as a Foreign Language (TOEFL), and interviews (see Boutaiba \& Strandgaard Pedersen, 2003; Mazza et al., 2005).

Transmutation is known from cultural theory and studies of religious symbols. It occurs when existing forms and practices are provided with new meaning and content. The MBA program at Uppsala University in Sweden illustrates this mechanism. The architects of that program rechristened an existing management training program the MBA program, changing virtually nothing about it (see Mazza et al., 2005).

Immunization is the flip side of imitation. Organizational leaders recognize new models but reject them, harboring existing conventions. Late adopters often engage in immunization before joining a bandwagon, as in the cases of the MBA programs at the Copenhagen Business School and Uppsala University (Boutaiba \& Strandgaard Pedersen, 2003; Mazza et al., 2005). Both schools defined the MBA as irrelevant to them and orthogonal to national needs until the early 1980s at Uppsala University and the late 1980s at Copenhagen Business School. Both schools had championed their alternative management education programs as functional substitutes suited to national needs. Yet when each school faced a crisis in its traditional management program, it jumped on the MBA bandwagon in search of legitimacy and an expanded client base.

\section{Conclusion}

Neoinstitutionalists find that organizations pursue isomorphism to gain legitimacy. Organizational culture scholars find that organizations claim uniqueness to establish their identities. We contend that these processes are not antithetical but are inextricable parts of a wider sociological phenomenon. An organization must make claims to being a recognizable member of a genus, and species, but it must also make claims to being a distinct member. The same is true for individuals. Whereas members of a biological genus share characteristics that are given by nature, members of the genus organization, or of the species frozen-pizza maker, share characteristics that are constructed in the interorganizational field. We see managers of individual organizations asserting their uniqueness on highly stylized dimensions. Frozen-pizza firms do not assert their uniqueness by claiming that all members are Capricorns or by constructing a culture organized on belief in alien abduction. They do not, even, claim that disempowerment is their thing. They may claim to cater to the upscale market, or to incentivize their workers with stock options, or to empower employees. Individual business schools may make claims about distinctiveness based on local industries or on the importance of language acquisition. The dimensions are stylizedinstitutionalized themselves. The roles are out there to be assumed.

Neither camp has, in our view, paid sufficient attention to the bridges between these two processes, of sameness and differentiation. We suggest that both camps might benefit from paying greater attention to the mechanisms that mediate the diffusion of new models of managing and the ways in which members of organizations translate, 
and react against, models from the field. When will organizations embrace new models wholesale? When will they mix them with old practices? When will they rechristen old practices with the trendy terms of the day? and When will they hold new practices at bay and cling to their old ways? Neoinstitutionalists have paid too little attention to what prevents adoption of a new practice-to immunization (but see Schneper \& Guillèn, 2004). And when they have studied diffusion, they have not considered whether "adoption" of a new practice is wholehearted, is really little more than renaming, or is really a combination of old and new. They might study immunization by looking at what prevents organizations from pursuing new trends, using prevailing methods but analyzing predictors of nonadoption rather than of adoption. Neoinstitutionalists could best study imitation, transmutation, and hybridization by carrying their research one step further into the organization. In surveys, they might delve into not only what broad practices are adopted but also how exactly those practices are implemented.

Among culture researchers, Martin et al. (1983) certainly recognized that organizations create distinct cultures from components found in the organizational field. What is unique about one organization tends to be "unique" as well about others of the same time and place. Organizational culture researchers could go further to identify the wider models in the organizational field that local organizational cultures are built from. Organizational culture scholars are sometimes too ready to accept their informants' stories about what makes the organization special. They too seldom hold the claim up to scrutiny. The study of how organizational practices are translated when they cross borders is a promising development (Czarniawska \& Joerges, 1996; Djelic, 1998; Sahlin-Andersson, 1996), but we still know little about how translation of new practices occurs within nations. Are truly distinct organizational cultures a consequence of immunization, by which managers define the local culture against some generic, uncharismatic, model of organizing? When organizations embrace new cultural elements, where do these elements come from? To what extent do these elements change in the process of translation? To answer these questions, students of culture need to pay more attention to what is going on beyond the borders of the organization.

\section{References}

Albert, S., Ashforth, B. E., \& Dutton, J. E. (2000). Organizational identity and identification: Charting new waters and building new bridges. The Academy of Management Review, 25(1), 13-17.

Albert, S., \& Whetten, D. (1985). Organizational identity. In L. L. Cummings \& B. M. Staw (Eds.), Research in organizational behavior (Vol. 7, pp. 263-295). Greenwich, CT: JAI.

Alvesson, M., \& Berg, P. O. (1988). Företagskultur och organisationssymbolism: Utveckling, teoretiska perspektiv och aktuell debatt [Corporate culture and organizational symbolism: Development, theoretical perspectives and current debate]. Lund, Sweden: Studentlitteratur.

Berger, P., \& Luckmann, T. (1966). The social construction of reality: A treatise on the sociology of knowledge. Garden City, NY: Doubleday.

Boutaiba, S., \& Strandgaard Pedersen, J. (2003). Creating MBA identity-Between field and organization. In R. P. Amdam, R. Kvålshaugen, \& E. Larsen (Eds.), Inside the business school: The contents of Euro- 
pean business education (pp. 197-218). Oslo, Norway/Stockholm/Copenhagen, Denmark: Abstrakt, Lieber, and CBS Press.

Brewer, M. B. (1991). The social self: On being the same and different at the same time. Personality and Social Psychology Bulletin, 17(5), 475-482.

Campbell, J. L. (1997). Mechanisms of evolutionary change in economic governance: Interaction, interpretation and bricolage. In L. Magnusson \& J. Ottosson (Eds.), Evolutionary economics and path dependence (pp. 10-32). Cheltenham, UK: Edward Elgar.

Christensen, S., \& Molin, J. (1995). Origin and transformation of organizations: Institutional analysis of the Danish Red Cross. In W. R. Scott \& S. Christensen (Eds.), The institutional construction of organizations (pp. 67-90). London: Sage.

Coase, R. H. (1937). The nature of the firm. Economics N.S., 4, 386-405.

Coleman, J. (1990). Foundations of social theory. Cambridge, MA: Belknap.

Czarniawska, B., \& Joerges, B. (1996). Travels of ideas. In B. Czarniawska \& G. Sevón (Eds.), Translating organizational change (pp. 13-48). Berlin, Germany: Walter de Gruyter.

Dacin, M. T., Goodstein, J., \& Scott, W. R. (2002). Institutional theory and institutional change: Introduction to special research forum. Academy of Management Journal, 45(1), 45-57.

DiMaggio, P. J., \& Powell, W. W. (1983). The iron cage revisited: Institutional isomorphism and collective rationality in organizational fields. American Sociological Review, 48, 147-160.

DiMaggio, P. J., \& Powell, W. W. (1991). Introduction. In W. W. Powell \& P. J. DiMaggio (Eds.), The new institutionalism in organizational analysis (pp. 1-40). Chicago: University of Chicago Press.

Djelic, M.-L. (1998). Exporting the American model: The postwar transformation of European business. New York: Oxford University Press.

Dobbin, F. (1994). Cultural models of organization: The social construction of rational organizing principles. In D. Crane (Ed.), Sociology of culture: Emerging theoretical perspectives (pp. 117-141). Oxford, UK: Basil Blackwell.

Frost, P., Moore, L. F., Louis, M. R., Lundberg, C. C., \& Martin, J. (Eds.). (1985). Organizational culture. Newbury Park, CA: Sage.

Gagliardi, P. (Ed.). (1990). Symbols and artifacts: Views of the corporate landscape. Berlin, Germany: Walter de Gruyter.

Gioia, D. A. (1998). From individual to organizational identity. In D. A. Whetten \& P. C. Godfrey (Eds.), Identity in organizations (pp. 17-32). London: Sage.

Glynn, M. A., \& Abzug, R. (2002). Institutionalizing identity: Symbolic isomorphism and organizational names. Academy of Management Journal, 45(1), 267-80.

Jelinek, M., Smircich, L., \& Hirsch, P. (Eds.). (1983, September). Organizational culture [Special issue]. Administrative Science Quarterly, 28.

Lant, T. K., \& Baum, J. A. C. (1995). Cognitive sources of socially constructed competitive groups: Examples from the Manhattan hotel industry. In W. R. Scott \& S. Christensen (Eds.), The institutional construction of organizations (pp. 15-38). London: Sage.

Leifer, E., \& White, H. (1987). A structural approach to markets. In M. Mizruchi \& M. Schwartz (Eds.), Intercorporate relations: The structural analysis of business (pp. 85-108). Chicago: University of Chicago Press.

Martin, J. (1992). Cultures in organizations: Three perspectives. New York: Oxford University Press.

Martin, J. (2002). Organizational culture: Mapping the terrain. Thousand Oaks, CA: Sage.

Martin, J., Feldman, M. S., Hatch, M. J., \& Sitkin, S. B. (1983, September). The uniqueness paradox in organizational stories. Administrative Science Quarterly, 28, 438-452.

Mazza, C., Sahlin-Andersson, K., \& Strandgaard Pedersen, J. (2005). European constructions of an American model. Journal of Management Learning, 36(4), 495-515.

Meyer, J. W. (1994). Rationalized environments. In W. R. Scott \& J. W. Meyer (Eds.), Institutional environments and organizations: Structural complexity and individualism (pp. 28-54). Thousand Oaks, CA: Sage.

Meyer, J. W., \& Rowan, B. (1977). Institutionalized organizations: Formal structure as myth and ceremony. American Journal of Sociology, 83, 340-363.

Peters, T. J., \& Waterman, R. H. (1982). In search of excellence. New York: Harper \& Row. 
Pettigrew, A. M. (1979, December). On studying organizational cultures. Administrative Science Quarterly, $24,570-581$.

Porac, J. F., Thomas, H., Wilson, F., \& Kanfer, A. (1995). Rivalry and the industry model of Scottish knitwear producers. Administrative Science Quarterly, 40(2), 203-227.

Røvik, K. A. (1998). Moderne organisasjoner [Modern organizations]. Oslo, Norway: Fakbolaget.

Sahlin-Andersson, K. (1996). Imitating by editing success: The construction of organizational fields. In B. Czarniawska \& G. Sevón (Eds.), Translating organizational change (pp. 69-92). Berlin, Germany: Walter de Gruyter.

Schein, E. H. (1992). Organizational culture and leadership: A dynamic view. San Francisco: Jossey-Bass.

Schneper, W. D., \& Guillén, M. F. (2004). Stakeholder rights and corporate governance: A cross-national study of hostile takeovers. Administrative Science Quarterly, 49(2), 263-295.

Scott, W. R. (1995). Institutions and organizations. London: Sage.

Scott, W. R., \& Meyer, J. W. (Eds.). (1994). Institutional environments and organizations: Structural complexity and individualism. Thousand Oaks, CA: Sage.

Selznick, P. (1949). TVA and the grass roots. Berkeley: University of California Press.

Selznick, P. (1957). Leadership in administration. New York: Harper \& Row.

Smircich, L. (1983). Studying organizations as cultures. In G. Morgan (Ed.), Beyond method: Strategies for social research (pp. 160-172). Beverly Hills, CA: Sage.

Strandgaard Pedersen, J., \& Dobbin, F. (1997). The social invention of collective actors. American Behavioral Scientist, 40(4), 431-443.

Van Maanen, J. (1988). Tales of the field: On writing ethnography. Chicago: University of Chicago Press.

Zucker, L. G. (1977). The role of institutionalization in cultural persistence. American Sociological Review, $42,726-743$.

Jesper Strandgaard Pedersen is associate professor in the Department of Organization and Industrial Sociology at Copenhagen Business School, Denmark. His research concerns cultural transformation processes in high-tech firms, occupational subcultures, mergers and acquisitions, and institutionalization of managerial ideas and practices. He has published his research in Organization Studies, Scandinavian Journal of Management, Journal of Management Learning, and Organization. Recent publications focus on changes in the media and business press field and on strategies for organizing and managing creative enterprises.

Frank Dobbin is professor of sociology at Harvard University. In 2004, he published two edited volumes that explore differences in economic practices with time and across countries: The New Economic Sociology: A Reader (Princeton University Press) and The Sociology of the Economy (Russell Sage). He is currently studying how power struggles shaped the rise of the shareholder value model of corporate governance; how national industrial policies evolved in the United States, France, and Britain since 1900; and how civil rights laws have affected the employment of women and minorities in American firms. 